Eastern Illinois University

The Keep

Faculty Research and Creative Activity

Sociology, Anthropology and Criminology

January 2013

\title{
Broke: How Debt Bankrupts the Middle Class
}

Michael D. Gillespie Ph.D.

Eastern Illinois University, mgillespie@eiu.edu

Follow this and additional works at: https://thekeep.eiu.edu/sociology_fac

Part of the Sociology Commons

\section{Recommended Citation}

Gillespie, Michael D. Ph.D., "Broke: How Debt Bankrupts the Middle Class" (2013). Faculty Research and Creative Activity. 1.

https://thekeep.eiu.edu/sociology_fac/1

This Article is brought to you for free and open access by the Sociology, Anthropology and Criminology at The Keep. It has been accepted for inclusion in Faculty Research and Creative Activity by an authorized administrator of The Keep. For more information, please contact tabruns@eiu.edu. 


\section{BOOK REVIEW}

Broke: How Debt Bankrupts the Middle Class, edited by Katherine Porter, Stanford, California: Stanford University Press, 2012. 320 pp. $\$ 80$ cloth. \$24.95 paper. \$24.95 E-book.

Katherine Porter, known for her work on consumer credit law and financial education, has edited a scholarly venture which addresses the mounting debt burdens and bankruptcy of middle-class families in the United States. As a unified project, this book utilizes Consumer Bankruptcy Project (CBP) data to examine how growth in consumer debt undermines financial security and prosperity. Not merely a collection of papers,the book examines different segments of the bankruptcy system where "the chapters together give a useful overview of the severe financial distress that plagues many American families struggling with their debts" (p. 10). Most contributions also supplement the CBP with analyses of other social science data, bolstering this project beyond a basic collection of papers on a particular subject. As the editor explains, "This book is designed to be accessible to anyone who wants a better understanding of the problems of consumer debt in American families and who has some familiarity with social science statistics" (p. 17). As an organized project, each chapter presents a certain picture of family bankruptcywhile citing information and arguments from many of the book's other contributors. In total, it is clear that Broke aims to be a targeted, detailed and comprehensive source of information on families in bankruptcy geared to an academic audience.

Porter, in the introductory chapter, offers context for the project as a whole,delineating the larger social, economic, and political conditions of bankruptcy. I note this chapter specifically because it contains a valuable baseline for the remainder of the project. Rather thanbriefly introduce the topic and summarize each contribution, this chapter begins with a description of a typical experience at a bankruptcy trustee's office, along with the incidence of such encounters-1.5 million in 2010-to argue for a "new normal" in the lived experience of families afflicted by the Great Recession. Prior to a lengthy introduction to the CBP, Porter provides an adequate historical and contemporary review of data on consumer debt, including debt-to-income ratios, consumer bankruptcy filings, and credit card charge-off rates. But what makes this introduction most useful is an addendum which outlines current bankruptcy law, and contrasts the two forms of consumer bankruptcies, Chapter 7 and Chapter 13, including a table of their major differences. 
Broke divides the remaining eleven contributions, including those from notable scholars Elizabeth Warren, Jacob Hacker, and Kevin Leicht, for example,across five thematic sections. Each section has relevance to the fields of economics, law, political science, psychology, and sociology, and, based on the interests of the reader, therefore makes the book readable in part or in total. Part 1, "The Debtor Next Door", provides a useful examination of bankruptcy filers by describing the demographic characteristics of bankrupt families. This portion is the most useful of the five sections because it details, on a macrolevel, the class-, race-, and gender-based vulnerability of families. Most notably, Chapter 2, "A Vulnerable Middle Class: Bankruptcy and Class Status," deconstructs the typical definition of the middle class as solely determined by household income; rather, an alternate definition is conceptualized to include, "educational achievement, job status, and homeownership" as "more valid measures of middle-class membership" (p. 29). These three dimensions supplement household income to show the intersecting catalysts of middleclass financial distress, subsequently providing the thematic base for the remainder of the book. In addition, by comparing CBP data over time with these other indicators of class status, the authors conclude that, in comparison to non-bankrupt families, "People in bankruptcy accomplished a great deal before this financial collapse, and they reflect a class status that is much like their counterparts around the country" (p. 38).

The middle three portions present specific analyses of each of the three markers of middle-class membership, unraveling the complexities of homeownership, educational attainment, and self-employment. Part 2, "Starting Right, Ending Wrong," separately contrasts life decisions that once seemed necessary for a middle-class lifestyle-higher education, purchasing a home, and owning a business-with the severe consequences each posses when debt burdens increase. Chapter 4 , for instance,examines how the costs of housing contribute to bankruptcy status, concluding that "homeownership may hamper the ability of some families to benefit from bankruptcy" (p. 84). Part 3, "Hurting at Home,"builds on the previous section to look at personalized experiences of debtors. For example, Chapter 7 questions why families in bankruptcy will go to extremes to keep their home, even if it means liquidating most of their other assets. Further, Chapter 8 introduces the important gendered-nature of debt management by exploring bankruptcy's toll on marital relationships. The household division of labor where"women tend to be responsible for low-control chores that have limited discretion or autonomy," means that women often bear the emotional burden of managing bills in financially distressed families (p.138). Finally, Part 4, "The Hard Road Out," describes attempts to negotiate the system by those persons who file for bankruptcy without legal representation (Chapter 9) and the significance of race(Chapter 10), which specifically, outlines the inequitable experiences ofbankrupt African-American debtors who are, on average, "less forgiven than debtors of other races" (p. 177). Together, these three sections reassess common, but misunderstood, markers of middle-class membership, and do so across gendered, racial, and class-based historical conditions of inequality and experience in the United States.

The final section, "The Once and Future American Dream," provides a pivotal, larger perspective on debt and financial distress. In addition to the volume's introduction and the Chapter 2's treatment of bankruptcy and class status, the final two contributions make this project, as a whole, laudable. Chapter 11 provides evidence of how the rise in consumer debt coincided with two other major shifts in the experience of middle-class families: wage stagnation and widening income inequalities. Moreover, not simply a treatment of data indicators, the conditions of existence in which such trends manifest are presented by discussing how the deregulation of the banking industry in the 1980s provided "structural changes in consumer credit" where "American families were offered more ways to borrow money, and more dollars of credit, against future earnings" (p. 205). Most interesting, this chapter provides a data simulation contrasting how the current debts of an average family would have been different prior to these banking deregulations, finding that "the debts of families in bankruptcy would have been dramatically reduced had they lived during the regulated credit market of the 1970s" (p.214). Likewise, Chapter 12 closes the book with a policy-oriented call-toarms in order to recreate a middle-class society in the United States. Here, common sources of economic opportunity-assets, workplace skills, education, and investments in children-are put in to focus "to construct a twenty-first-century social contract to protect families" and "provide a sufficient cushion against these adverse shocks [leaving] families borrowing to try to make ends meet" (p. 233).

I consider this book, in line with the recommendation of the editor, best suited for graduate programs, particularly those in law school or a number of the social sciences, especially schools of public policy, or courses in sociology or social welfare. The extended use of the CBP, and the emphasis on empirical analyses - often times beyond those covered in undergraduate methods and statistics courses-make this project ideal for graduate work. Necessarily, this volume includes a detailed appendix on the background, sampling techniques, response rates, and other aspects of the CBP. But to further promote its educational focus, the book is also supplemented with online resources including additional data and tables, and sample syllabi for upperdivision and graduate courses.

For the appropriate audience, Katherine Porter has edited an important contribution to the literature on family economic distress, the lived-experience of families in debt, and related issues ofthe intersections of social class, gender, and race with each other, as well as education, employment, and homeownership. Yet, with such an important topic, caution should also be introduced given the amount of data and reliance on statistical analyses. It is clear that the project was conceived as an academic exploration, but such important analyses need to be distilled to an accessible format and offered to a broader constituency. While several contributors have written outside of the 
academy or within governmental and policy circles, most notably Elizabeth Warren and Brian Bucks, Broke still leaves such a comprehensive discussion of economic inequality within a certain privileged and educated-class. Refining these themes and their arguments can benefit those who live these lives every day, and to those who, given their status, are charged with designing the social policies through which the lives of bankrupt families are most implicated. Perhaps, when used in graduate programs in law, social work, or other fields whose practitioners confront these issues, advocates can utilize this valuable resource in their daily work.

Michael D. Gillespie Eastern Illinois University

Illicit Flirtations: Labor, Migration, and Sex Trafficking in Tokyo, Rhacel Salazar Parreñas, Stanford, Stanford University Press, 2011. 325 pp. \$64.35 hardback, \$21.95 paperback, \$10.99 Kindle.

In the first years of the $21^{\text {st }}$ century, the United States government declared a war on human trafficking,a term thatis defined broadly. As part of its war strategy, the US State Department limited aid to countries identified as sites of trafficking. Countries on this list arealso subject to "social ostracism" in the international community (53) and,consequently, states identified as sites of human trafficking are motivated to thwart trafficking channels by restricting the migration of peoples whoare identified as "trafficked."

Rhacel Salazar Parreñasinterrogates the human trafficking paradigm that has been set forth by the US State Department and investigates the real-world consequences of policies designed to prevent trafficking. Parreñas takes the reader deep into the heart of the Tokyo Filipina nightclub hostess community, which the US State Department identifies as the largest group of sex-trafficked persons in the world. To comply with US demands and maintain US aid, as well asto avoid social ostracism in the global community, both the Japanese and Philippine governments have enacted laws to regulate the migration of Filipina nightclubhostesses to Japan.

During the nine months that she spent researching and working as a hostess in clubs run by the Yakuza, Japan's notorious organized crime syndicate, Parreñasinvestigated the phenomenon of trafficking and the effectiveness of anti-trafficking policies. Through her work at the nightclubs, she interviewed 45 female migrant hostesses and 11 transgender migrant hostesses. While she found that the working conditions in Tokyo's hostess clubs arenot ideal and some women go unpaid, she questions the explanation that hostesses are victims of sex trafficking and asks to what degree it is actuallygovernment policiesthat harm women.

Parreñasis a master of nuance. In exploring the complexities of the hostess situation, her meticulous research shows that the trafficking and rescue paradigm that has been adopted by the US, Japan, and the Philippines is over simplified and deeply flawed.This paradigmis predicated on the assumption 